\title{
AJAR DOOR TO PRIVATE INTERESTS IN WATER (DRINKING WATER SUPPLY) MARKET - RARE CASE OF SLOVENIA, TRIGGERED BY THE EU PROPOSAL OF THE DIRECTIVE ON CONCESSIONS
}

\author{
Rajko Knez*
}

\begin{abstract}
This article discusses a new constitutional right, a right to (drinking) water in Slovenia, especially elements of the public service for the supply of drinking water. This change of the Constitution was triggered by the 2011 proposal of the EU Directive on concession, which had proposed concessions for the supply of drinking water. A harsh reply from the wider public changes the mainstream of this idea. At the same time, it had triggered certain political sphere to think how to preserve the supply of drinking water out of the private interests. Corollary, in Slovenia, the supply of drinking water is taken out of the market, that way also from the EU internal market and the competition rules, which both might be contestable. Arguments are put forward to support the exclusion of the above services from overall water market, claiming that the supply of drinking water has certain distinctive elements from other public services, where the natural resources are not in foreground, especially where every individual is not only potential, but real end-user. The article emphasizes that the measure is more important for future generations and for our inheritors and adds supportive arguments in this respect.
\end{abstract}

KEYWORDS: right to water, concessions on water market, public service for drinking water supply.

\footnotetext{
Judge at Constitutional Court of the Republic of Slovenia and full professor at University of Maribor, Faculty of Law; rajko.knez@um.si.
} 
Notice:

The author was a member of the expert group which task was to prepare a draft of the constitutional provision on the right to drinking water. The group prepared a proposal which was not fully accepted by the Parliament. The opinions presented in this article are independent opinions of the author.

\section{INTRODUCTION}

Not long ago, in November 2016, Slovenian Parliament voted for a change of the Constitution of the Republic of Slovenia (hereinafter Constitution); the change refers to the right of drinking water. A new article, Art. 70.a, was inserted in the Constitution regulating the right to drinking water as a human right (a right given to everybody). ${ }^{1}$ It also accepts that water resources are public good and in the management of the State. Next, it defines that water resources primarily serve to supply inhabitants with drinking water in accordance with the principle of sustainability. In this respect, in this is the emphasis in this article, water resources shall not be deemed as a commodity when they serve to drinking water supplies. Finally, new article defines that supply with drinking water has to be assured by the State throughout the local communities directly in so called "non-profit mode".

The main emphasis of this constitutional rule shall be given to its goals, i.e. to secure water resources from overexploitation for the sake of current and above all for the sake of future generations ${ }^{2}$ and to make exploitation of water resources unattractive to private capital.

\footnotetext{
1 Article 70a reads: (Right to Drinking Water)

"Everyone has the right to drinking water.

Water resources shall be a public good managed by the state.

As a priority and in a sustainable manner, water resources shall be used to supply the population with drinking water and water for household use and in this respect shall not be a market commodity.

The supply of the population with drinking water and water for household use shall be ensured by the state directly through self-governing local communities and on a not-for-profit basis."

As amended by the Constitutional Act Amending Chapter III of the Constitution of the Republic of Slovenia, which was adopted on 25 November 2016 and entered into force on 25 November 2016 (Official Gazette of the Republic of Slovenia No. 75/16).

2 Underground water in Slovenia, in most parts, sinks for years and the predictions for the future are not good. From this point of view, it is not enough that we estimate that there is enough underground water in this very moment, but one shall think what will happen to our posterity in the future. Even though there are sufficient supplies of underground water right now, this cannot be the sole reason to pump it and sell it without limitation. Like it is written in Constitution of USA in the preamble (but also there this is forgotten ...) "to promote the gen-
} 
Facing with bad examples across the world, facing also with the incentive by the European Commission in the draft Directive on concessions in 2011 to call up private capital in the sphere of the supply of drinking water (by way of concessions) and faced with the all European movement of EU citizens (Right2 Water $^{3}$ ) it had been proposed to the Slovenian Parliament, already some years ago, to prepare such a change of the Constitution. This proposal was reinforced based on Commission notice on the right to water initiative (the Commission did not proclaim drinking water as a commodity). ${ }^{4}$ Slovenian Parliament made a detailed comparative research in European states and also beyond (jurisprudence of the ECtHR), which acknowledges that some states are also trying to preserve water resources and to regulate the management of the supply with drinking water in the Constitution or on the legislative level. ${ }^{5}$ The Parliament did not hide the intention to limit the supply of drinking water only to public management and to shift it away from private sphere (in addition to the fact that the water resources shall remain public good with no possibility to gain ownership over the water resources). This means not only the legal nature of the water resources (and water itself being regulated as a public good), but the Constitution also addresses the administration and the management of the supply of drinking water.

eral Welfare... to our Posterity" i.e. one shall think of applying the principle of sustainability for our inheritors. This by its own words means that we have "to sustain" from actions which will have negative effects in the future.

The above facts on availability of the underground water can be find in the yearly report (by ARSO; see: Količinsko stanje podzemnih voda v Sloveniji, Osnove za NUV 2015-2012, http:// www.arso.gov.si/vode/podzemne\%20vode/). It reports on the level of the underground water, its quantity and quality, which is decreasing in Slovenia. Corollary, we should take care of the underground water, thinking how to increase its quantity and not how to sell it.

Preserving water resources is not so much the question of the present (app. 87\% of Slovene inhabitants uses water supply services in Slovenia per the competent ministry, State Council, 001-02/15-1, 11.5.2016), but for the future generations. This is also a question, whether we can now act contrary to interests of our posterity, our children. Pumping, bottling and selling water are not acts of necessity for our generation, but the acts of the interest of the capital (private interest). It is an act of necessity to get financial founds and is not an act of survival (necessity) of today's generation; that is rather a huge difference.

3 http://www.right2water.eu/ (acc. 1.12.216)

4 Communication from the Commission on the European Citizens' Initiative "Water and sanitation are a human right! Water is a public good, not a commodity!" Brussels, 19.3.2014 $\operatorname{COM}(2014) 177$ final.

5 Igor Zobavnik, Pitna voda - Primerjalni pregled, RS Državni zbor, Raziskovalno-dokumentacijski sektor, Ljubljana, 2015. In this respect see also The Rt Hon lady Justice Arden, Water for all? Developing a human right to water in national and international law, ICLQ vol 65, October 2016, str. 771-789, also Pravna klinika za varstvo okolja, 2014/2015, Odgovornost države zagotavjati pravico do čiste pitne vode, več avtorjev, Ljubljana, July 2015. 
The critics expressed, which followed the proposal and later also the accepted constitutional rule, pointed out that the rule is not necessary and that right to drinking water is already comprehended by the right to healthy living environment (Art. 72 the Slovene Constitution) and that is not appropriate to close a water market. ${ }^{6}$ This article addresses these issues together with some other viewpoints and the analyses. Although the access to drinking water and its supply was not, prior to the mentioned change, regulated in the Constitution, I had certain sympathy to such critics several years ago, when the first proposal was given to the Parliament to regulate the right to drinking water. However, after several studies, comparative solutions, the viewpoints of the European Commission $^{7}$ and after taking into account a changed environmental climate and realizing the decreasing resources of drinking water (for decades now) made me totally rethink my position. The following article is therefore also a list of arguments of cognizance made on my personal level and stimulated me to rediscover and hence to change my position towards a constitutional regulation of the right to drinking water. ${ }^{8}$

\section{ANALYSIS OF THE APPROACH}

At the outset, before addressing the arguments for some solutions in the new constitutional rule, let me first address some aspects of the taken approach. The following are the most important effects of new Art. 70a of the Constitution:

- water resources shall be used predominantly for the supply of drinking water for the benefit of all inhabitants;

- the supply of drinking water shall have priority over any other use of drinking water resources (like any commercial use for industry, bottling of drinking water, etc.);

- drinking water resources shall be used in accordance with the principle of sustainability; meaning that every water resources capacity and quality shall be assessed in terms of a long-term ability for uninterrupted supply of it;

\footnotetext{
$6 \quad$ See in this respect Matej Avbelj, 'Pitna Voda: Ustavna prepoved in ne pravica' 24.11.2016 Pravna praksa p. 3.

7 See more detailed Communication from the Commission on the European Citizens' Initiative "Water and sanitation are a human right! Water is a public good, not a commodity!"

8 See also Aleš Ferčič and Rajko Knez, 'Organizational Challenges of the (Local) Water Supply in the European Union Member States' (2015) 13 Lex localis - Journal of Local Self-Government 765.
} 
- especially in countries like Slovenia, where the resources of water are still in good conditions, the municipalities shall perform the public services for the supply of drinking water "directly" (explained more in detail bellow); 9

- the municipalities shall perform the supply on drinking water on non-profit base (explained more in detail below).

\subsection{A DIRECT SUPPLY OF DRINKING WATER}

Drinking water can be seen as a (final) product $^{10}$ (which can, in general, also serve for the satisfaction of capital). If water resources are numerous and rich

9 The municipalities have already been competent to perform the public service of the supply of drinking water; i.e. according to Art. 149 of the Environmental protection act OJ of the RS, Nrs. 41/2004, 17/2006 - ORZVO187, 20/2006, 28/2006 - skl. US, 49/2006 - ZMetD, 66/2006 - Decision of the Con. court, 33/2007 - ZPNačrt, 57/2008 - ZFO-1A, 70/2008, 108/2009, 48/2012, 57/2012, 92/2013, 38/2014, 37/2015, 56/2015, 102/2015, 30/2016, 42/2016.

10 Especially in countries like Slovenia, where the resources of water are still in good conditions, despite the lowering of the underground water resources. For data regarding the lowering of the ground water storage see: Agencija RS za okolje (ARSO), 'Količinsko Stanje Podzemnih Voda v Sloveniji - Osnove Za NUV 2015-2021', <http://www.arso.gov.si/vode/podzemne\%20 vode/publikacije\%20in\%20poro\%c4\%8dila/Kolicinsko_stanje_podzemnih_voda_v_Sloveniji_OSNOVE_ZA_NUV_2015_2021.pdf > accessed 14 January 2017.

This document assesses the condition of underground water as good, however it assesses also the lowering of the underground water is not increasing. Further on, it also states that the underground water is subject of increased values of indicative parameters of natrium and chlorine mineralisation (on some spots). To this is important to add scientific conclusion of United Nation documents.

In this respect, Agenda 21 - the document of the United Nations Conference on Environment and Development (UNCED) in Rio de Janeiro 1992 - acknowledges that higher temperatures are lowering the rain volume, changing the structure of the rain (due to climate changes the rain is faster, more intense, it does not trickle through the earth and a linkage, necessary to fill underground water resources, becomes less and less sufficient. The rainwater, due to stormy rain water, therefore ends up in rivers and torrents rather than and increasing the need for water. Agenda proposes measures to the states, which would assure and protect water resources due to the climate changes. Accessible on: https://sustainabledevelopment.un.org/content/documents/Agenda21.pdf (14 January 2017).

All mentioned above is important also from the viewpoint of the new constitutional provision for the right to drinking water - basically, this provision is not headed towards nowadays generations but for future generations. Is should assure enough drinking water for our posteriors yet to come with all their needs for drinking water. From this point of view this provision is among rare provision, which is oriented for the future. Usually, especially in modern development of law, legal solutions are regulating current relations or even relations which happened in the past and gave reasons for the legislator to react. Provisions which would secure our posteriors are indeed rare. Simona Drevenšek, Jan Bratinič, 'Voda Je Velik Osel' Cvet kapitala-poslovni tednik Dela (1 June 2017) p. 12-14. 
and if the water is of good quality, distribution of drinking water is not a huge problem and neither the investment in the infrastructure. Namely, especially in comparison to other communal services like waste-water treatment, electricity, road infrastructure etc. the water supply does not face such huge investments. The infrastructure can be easier built up also in agitated relief like in Slovenia, altitude difference can be solved with the pressure, etc. Actually, this is proven practice in Slovenia - expensive infrastructure for the waste-water is far from built up in Slovenia. ${ }^{11}$ On the other hand, even remote parts of Slovenia are served with the supply of drinking water.

In addition to structural and doctrinal issues, the water itself is the final product (it does not have to be manufactured and there are basically no production costs). Another important element is that the clients (end-users) are known in advance (basically every individual). These elements make water very attractive to private capital (to be used for bottling or other production and even to perform distribution and supply services). The above distinguishes, rather substantially, the use of water in comparison to any other natural resources. ${ }^{12}$ For instance, if we compare the exploitation of forests or minerals, the picture with water supply is totally different. From these reasons the Slovenian Parliament's action and its position that the supply of drinking water shall be made less attractive to private capital can be understood. The Parliament wanted to retain the supply services for the public sphere. This is visible by using the word "directly" (above) in the new Article 70a, i.e. that the supply of drinking water shall not be performed outside the public sphere. If this term is to be properly understood, then the supply shall not be performed through private companies by the way of concessions being rewarded by municipalities. Although Slovenian Law on public private partnerships ${ }^{13}$ foresees that public services can be performed by way of the concessions (and the same goes for

\footnotetext{
11 In 2014 appx. 10,7 mio. $\mathrm{m}^{3}$ untreated waste water were released directly to surface waters $(65,6 \%)$ and to underground waters $(34,4 \%)$. See in this respect statistical data of the statistical office of the RS, accessible here: http://www.stat.si/StatWeb/en/show-news?id=5246\&id$\mathrm{p}=13$ \&headerbar $=8$ (14 January 2017). According to the statistical data the relation between process for drinking water supply and wastewater treatment is slightly above 1:2 (0,66 eur per $\mathrm{m}^{3}$ in Dec. 2016 for drinking water and 1,43 eur per $\mathrm{m}^{3}$ for waste water treatment (source: http://pxweb.stat.si/pxweb/Dialog/varval.asp?ma=0411001s\&ti=\&path=../Database/Ekonomsko/04_cene/04110_povpr_dpc/\&lang=2). In my opinion this proportion should be rather 1:4 taking into account investments for waste water treatment, necessary knowledge, energy needed, duties, etc.

12 Of course, the oil is also a product of nature like minerals, etc. There are, however differences to the drinking water with respect to the technology and equipment used for the exploitation, its necessity for every single individual, economic reasons, etc. Drinking water is easier accessible, widely necessary for life, final product by itself, etc.
}

13 OJ of the RS, Nr. 127/06. 
the Services of General Economic Interest Act ${ }^{14}$ ) the Constitution now foresees otherwise. It remains a question, however, if the term "directly" will be given a meaning as described.

The above is rather important to understand. Namely, reasons pointed out above make water as a natural resource distinguished from other natural resources. One should use other natural resources only as raw material which still has to be processed etc. (like ore, raw oil, etc.). Water, however, has only to be pumped out (where necessary), monitored and filtered. The processes of supplying drinking water are less sophisticated and complicated. ${ }^{15}$

To recapitulate, the supply of drinking water shall be organized exclusively throughout the municipalities and throughout their public companies or other public entities. In practice this is already the fact in the most parts of the country. ${ }^{16}$ Since Slovenia consists of 212 municipalities and since many of them are rather small in terms of number of inhabitants as well as in terms of the territory, many of them have organized the supply of drinking water jointly by engaging their public companies or by awarding the concessions. ${ }^{17}$ One can anticipate that there will not be 212 different public companies for the supply of drinking water across the country. ${ }^{18}$

This part of the provision, that the supply of drinking water shall be made directly as stated above, excludes private capital and private service providers from the market. This shall be discussed also in the light of the EU law and the internal market rules as well as the competition rules. Treaty for Functioning of the EU (hereinafter TFEU) also obliges undertaking with exclusive rights to respect competition rules (Art. 106) to the extent that the public service would

\footnotetext{
14 OJ of the RS, Nr. 32/93, 30/98 - ZZLPPO, 127/06 - ZJZP, 38/10 - ZUKN in 57/11 - ORZGJS40.

15 Rhys Andrews, Goerge A. Boyne, Richard M. Walker, 'Dimensions of Publicness and Organizational Performance: A Review of the Evidence' JPart 21 Journal of Public Administrationn Research and Theory i301.

16 Municipalities usually also own the water supply infrastructure.

17 However, only 8 public companies take care of the supply of $49 \%$ territory of Slovenia. Strokovna skupina za pravico do pitne vode, Mnenje o predlogu za začetek postopka za spremembo Ustave RS z osnutkom ustavnega zakona - pravica do pitne vode (EPA 463-VII), št. 001/02/15-4, 9.3.2016.

18 This article does not deal with a question whether the supply should be managed by state or by municipalities. This is rather another issue, which would demand analyses of good and bad practices. They all are present in Slovenia. In short, each municipality has its own interests, difficulties and sometimes also profits in suppling drinking water. Prima facie there are too many performers for 2 mio inhabitants in Slovenia.
} 
not be jeopardized. However, as stated in the Commission communication $^{19}$ the supply of drinking water can be taken out of this provision in case it is not offered on the market. Namely, it is a question whether the supply of drinking water is a commodity or not. The Commission supports, in this sense, the initiative Right2Water and does not contravene this viewpoint. Also, even without it, it should be pointed out that the measure creating a dominant position by granting exclusive rights within the meaning of Art. 106 is not by itself incompatible with TFEU as long as public companies satisfy the needs of the public and as long as the service in question is not extended to the territory of another Member State. It is rather unclear whether Art. 106 would be applicable in a case where Member States prohibit the performance of drinking water supply to private companies. To this respect, it is important that the European Commission stated that water supply and management of water resources should not be a subject to internal market rules and that the water services shall be excluded from the liberalization processes:

"Referring to the concerns expressed by the citizens' initiative that water supply and management of water resources should not be subject to 'internal market rules' and that water services be excluded from liberalization, the Commission confirms that public procurement legislation does not apply when local authorities decide to provide the services themselves, through a joint venture or through an affiliated undertaking." 20

This viewpoint of the European Commission, although in the soft law, is important and clarifies its position towards the cases like Höfner, Ambulance Glöckner, Corsica ferry, Centre d'insemination de la Crespelle, etc., where the EU Court of Justice made positions that the companies with the exclusive rights (also public companies) need to respect internal market and competition rules. $^{21}$

19 European Commission, 'Communication from the Commission on the European Citizens' Initiative "Water and Sanitation Are a Human Right! Water Is a Public Good, Not a Commodity!",

20 ibid. p. 5

21 Cases, C-475/99 Firma Ambulanz Glöckner v Landkreis Südwestpfalz, ECLI:EU:C:2001:577, C-18/93, Corsica Ferries Italia Srl v Corpo dei Piloti del Porto di Genova, ECLI:EU:C:1994:195, C-323/93 Société Civile Agricole du Centre d'Insémination de la Crespelle v Coopérative d'Elevage et d'Insémination Artificielle du Département de la Mayenne, ECLI:EU:C:1996:282, C-41/90, Klaus Höfner and Fritz Elser v Macrotron GmbH. ECLI:EU:C:1991:161, C-260/89 Elliniki Radiophonia Tiléorassi AE and Panellinia Omospondia Syllogon Prossopikou v Dimotiki Etairia Pliroforissis and Sotirios Kouvelas and Nicolaos Avdellas and others, ECLI:EU:C:1991:254. 


\subsection{A NON-PROFIT MODE OF THE SUPPLY OF DRINKING WATER}

Per Art. 70a of the Constitution the public companies shall perform public service for the supply of drinking water on non-profit base, meaning that they should calculate the costs and reinvest all the above-costs income gained. The price will be publicly supervised (as it is right now). It means that the individual performer of supply services should prove the costs of the supply in advance and that municipal authorities will define the price accordingly. The costs will have to consist also from the anticipated investments. The water itself is not payable, however the use of water is. ${ }^{22}$ In Slovenia the use of water is set to 0,0638 EUR per $\mathrm{m}^{3}$. Other parts of the price payable by the individual service recipient of drinking water consist of costs for the supply and the use of the water supply infrastructure.

New Art. 70a therefore defines a new framework in which the supply of drinking water shall be organized in the future. The existing concessions will, most likely, not be revoked or will not cease. If contrary, this would be a case of vested rights and the liability for damages can occur.

However, new concessions will not be possible. As it is discussed above, it remains to be seen, whether the direct supply of drinking water will be understood as a prohibition to award concessions.

The above was one, among others, of the critics. In this respect, it is of course disputable whether private interest (private capital) is rightly excluded from the water market. It is also well known that private capital can usually organize and manage certain public services to be performed more efficiently but there is a question also if this means, at the end of the day, also a better service and also a better (lower) price for the end-users. On the other hand, publicly owned companies could lack the efficiency and market approach. Some authors claim that there are no such indications and those available are not founded on serious research projects in this regard. ${ }^{23}$ However, other are claiming differently, by maintaining that public companies can be even more efficient, taking more care for a preservation of the environment, uses lover tariffs (i.e. prices), taking more care for the infrastructure etc. ${ }^{24}$

Public and private entities can also come very close together; a public performer can be very effective, very diligent in pursuing the public interest and economic performance of public service, or none of these. On the other hand, a private performer can be only profit oriented, be effective only because of the

22 Decision determining the price of water charge basis for the use of water, alluvial deposits and water areas for 2016, OJ of the RS, Nr. 106/15.

23 Rhys Andrews, Goerge A. Boyne, Richard M. Walker (n 15).

24 Golobič, Pirnat, p. 98, 99. 
profit, without bearing in mind a prevailing public interest in performing the public service and therefore the price for the end-users shall not differ a lot, if at all, in comparison to public performer.

In other words, a public performer can do a good job, as well can a private performer do a good job, however, for its own interest not for the public. The question of the quality of the public service performance is, therefore, not a question of being publicly or privately organized. It is predominantly a question of a personal subtracts of the service performer, i.e. individuals in charge. Also the corporate structures in public companies can be very efficient. It is true that private companies are driven by the private interest which aims to the best possible use of human and other resources, and that therefore the results (in economic terms might be better in private sphere). And this is the breaking point - the basic difference is, that when a privately organized capital uses natural resources also for its own profit, the conflict of public and private interest is immediately present. To apply this affirmation to the sphere of water - the public interest is to use the water as a common good and the private interest is to use it as a commodity.

All these have to be assessed also in different circumstances, i.e. under different concessions. If one compares a concession for the waste-water treatment with a concession for supply of the drinking water, where both are public services, the difference is nevertheless huge. The concession for waste-water treatment will demand from a concessionaire a huge investment on the waste-water treatment facility and the infrastructure and, importantly, the concessionaire will not be dealing at all with natural resources. Neither of these two elements (especially the later) are present in the sphere of the concessionaire for the supply of drinking water.

As maintained above, the facilities for drinking water supply are not so complicated and sophisticated, the distribution infrastructure, at least in Slovenia, is mostly built and above all the natural resource is at stake. Indeed, it is a renewable natural resource, but as it is presented above (n 2), the quantity is decreasing, and the climate changes also influence the decrease.

Actually, water is like no other natural resource; it is a final product and consumers, end-users - i.e. every individual, are known in advance (basically no market strategy is necessary). ${ }^{25}$ In fact, many authors are discussing the effects of private companies using the natural resources, usually for pursuing private

\footnotetext{
25 Even the producers of bottled water freely admit that the water is a big business. Average growth of consumption of the bottled water in Europe is 5,6\%. Let me add to this that according to the statistical data the marketing of bottling water is 100 times bigger than in 1980, also in states where tab water is of good quality. Simona Drevenšek, Jan Bratinič (n 10). However, the reader shall be well informed that the market for bottling water is not closed with this constitutional provision. It is only closed for the supply of drinking water (households) and from the underground resources, which serve for the supply of drinking water (also households).
} 
interest. They claim that it does not help the state to acquire more wealth neither will this have such effect on their citizens. ${ }^{26}$ One can learn this from comparison from other countries. Slovenia as well has one important bad example by awarding concessions to manage (i.e. exploit) the forests. ${ }^{27}$

If public companies are engaged in performing public services, the political and not market forces are the ones, which are to be obeyed. Public companies are also accounted to the governments and to the citizens, which is not true for private companies. ${ }^{28}$ However, political control, if the state is well functioning (state level or understate levels like municipalities) can be efficient and perhaps even easier performed in contrast to control over the concessionaires. If political control establishes that certain public company is not performing its duty well, the action taken can be quick, one-sided and efficient. The same cannot be said for the control over the private public service performer. In such a case, usually, the concession agreement will protect concessionaire from any one-sided and immediate measure from the public partner and political control will therefore not be affective. ${ }^{29}$

\section{THE CONCLUSION}

The object of the above discussed new approach in Slovene constitution is attained, ${ }^{30}$ however, it is also criticized. ${ }^{31}$ Critics basically emphasize that the wa-

26 Different authors are writing on this issues as being cursed by natural resources; Donato De Rosa and Mariana Iootty, 'Are Natural Resources Cursed? An Investigation of the Dynamic Effects of Resource Dependence on Institutional Quality' The World Bank Europe and Central Asia Region Financial Sectors Development July 2012; Kolar, Tea, 'Vloga prava $\mathrm{v}$ procesu prilaščanja in prekomerne rabe naravnih dobrin' $<\mathrm{http}$ ://www.jm-excellence.si/wp-content/uploads/2014/01/Student-paper-Nr-2-Tea-Kolar-Vloga-prava-v-procesuprila\%C5\%A1\%C4\%8Danja-in-prekomerne-rabe-naravnih-dobrin.pdf $>$ accessed 18 December 2016; Kirn, Andrej, 'Ekosicalizem Kot Povezava Družbenosti in Sonaravnosti: Realna Alternativa Ali Utopija' 2016 Varstvo narave 49;

27 With respect to Slovenian unfortunate example on concessions management of Slovenian forests also the Court of Auditors of the RS established a miss functioning. See in this respect the decision of the Court of Auditors of the RS, Nr. 321-2/2010, of 27.10.2010.

Pihlar, Tatjana, 'V Slovenskih gozdovih se na veliko krade' (Dnevnik) <https://www.dnevnik. si/1042536338> accessed 18 December 2016.

28 Rhys Andrews, Goerge A. Boyne, Richard M. Walker (n 14), p. i302.

29 ibid., p. i304-i305.

30 See for similar approaches THE RT HON LADY JUSTICE ARDEN, WATER FOR ALL? DEVELOPING A HUMAN RIGHT TO WATER IN NATIONAL AND INTERNATIONAL LAW, ICLQ vol 65, October 2016, p. 771-789.

31 See for different opinion Matej Avbelj, Pitna voda: ustavna prepoved in ne pravica, in Pravna praksa, of 24.11.2016, p. 3. 
ter is already protected by the Constitution (protection of natural resources) ${ }^{32}$ and that the area of the supply of drinking water shall be left open to private initiative/capital. They argue that Art. 70a is not giving the right to water, but is rather a prohibition. Personally, I think this is questionable; namely, supply of drinking water is of public interest, the main "product" is given by the nature itself and it is not given for the satisfaction of the private capital but for the satisfaction for common interest. Concessions for the exploitation of natural resources shall be considered differently from all other concessions like concession of services, especially where advanced knowledge is necessary. Technical solutions for more sophisticated services might be better solved by private companies with well-developed research \& development units (R\&D) and programs. But above all, natural resources aimed for the satisfaction of wide public interest remain in public management. Therefore, all concessions cannot be treated the same. Those with the exploitation of natural resources shall not be treated as others. ${ }^{33}$ The approach taken by the Slovenian Parliament will have effect for the future generations, for our inheritors. Although striking and criticized, one can hardly not see the positive impact in this respect.

At the outset, it is also true that a public company can perform water supply management well, as well as private one and vice versa. Even public company, not only private one, can exploit natural resources with certain misuse, unnecessary profit gain, use the public interest as its own internal interest, etc. ${ }^{34}$ However, public companies are accountable to wider public, to politics and authorities, whereby the private companies are not. In the latter case the level of surveillance depends from appropriateness of the concessions' rules. A public sphere is easier to be controlled, panelized, income gained from water supply can easier be reused for reinvestments or for maintaining the infrastructure, for construction of new infrastructure to areas where there is no water supply, etc.

\footnotetext{
32 However, the Constitutional Court had a chance to invoke right to water under Art. 72 (Right to a healthy living environment) but it did not. The case Up-156/98 of 15.6.1998 concerned the declination of drinking water supply by the service provider and the Constitutional Court was of the opinion that ownership right to the condominium is violated this way. It did not refer to the right to water.

33 See also Joseph Stiglitz, Vračanje prekletstva resursov, Finance 158/2004, 16.8.2004; Gorger Soros, 'Prekletstvo Naravnih Virov' (Finance.si) <https://www.finance.si/52901> accessed 19 January 2017.

34 For instance, exporting water to Asia from one of the Slovene municipalities (Maribor) (see news Mariborski vodovod bi vodo prodajal v Azijo, DELO, 17.10.2015), of course, benefits the public company (indirectly municipality), but this is only an economic reason for present generation. It is rather questionable how justifiable is such reason for future generations. Namely, as long as reductions of water supply are necessary in case of two to three months' period of time without any rain, one can hardly imagine that the water resources are rich enough. This is not a sustainable use of water resources, as is stipulated in new Art. 70a.
} 
A public control over founding, price management, technical issues, etc. are much easier to be accountable in case of public companies. ${ }^{35}$

Regulating water at the constitutional level cannot, due to all elements and characteristics described above, be seen as regulating any other natural resource. Only once all these elements are taken into account, it can be understood why special regulation, even on the constitutional level, is necessary; applying general rule on natural resource protection and to the right to healthy environment might not be sufficient in case of drinking water supply. This is also illustrated by Constitutional Court decision in which the supply of drinking water was not to seen as a right of an individual (not as ratio decidendi, also not as obiter dictum). Moreover, Constitutional Court ${ }^{36}$ did not question the balance of the right to water and non-payment for supply services. Such an evaluation and an assessment would be necessary (whereby the result at the end might be the same, i.e. to stop with the supply in the case of non-payment) but the bottom line is that the Constitutional Court did not recognize the right to drinking water as a part of a right to healthy leaving environment but rather it linked the water supply to the ownership right of the condominium. From my point of view this is not sufficient. The right to water shall exist also in cases where an individual is not an owner or the proprietor of the immovable. ${ }^{37} \mathrm{Such}$ a viewpoint excludes anyone that is an owner or a proprietor of the immovable (which also needs to have a right to a junction to the water supply) from the constitutional protection. What would be reactions of courts in the future if the right to water would not be regulated at the constitutional level, without Art. $70 \mathrm{a}$, is less clear and more difficult to anticipate. As noted above (n 2), this provision is not so important for nowadays, but for future generations.

The constitutional rule did not ban the water market in whole; the water remains to be free on the market for industrial and commercial use like bottling water, water used in spas, hydropower plants, water needed to brew bear, etc., but the supply of drinking water to the households shall only be allowed to public companies and managed by the municipalities. Another limitation,

35 See Rhys Andrews, George A. Boyne, Richard M. Walker, Dimensions of Publicness and Organizational Performance: A Review of the Evidence, in: Publicness and Organizational Performance: A Special Issue, Jpart 21:i301-i319.

36 See the Decision of the Constitutional Court, Up-156/98 of 6.5.1998. Despite this decision there is a practice in Slovenia that municipality close water valve and disconnect the supply of drinking water in case of non-payment for water supply services (decision of the mayor of municipality Krško, No. 355-6/2015 of 19.02.2016). This is differently regulated in France, see in this respect Zobavnik, ibid. n 5, p. 8-9.

37 See for the opinion 'Jadranka Sovdat: Ustavno Sodišče ne more biti medijska senzacija!' (Dnevnik) <https://www.dnevnik.si/1042757014> accessed 25 December 2016. 
which would like to secure underground water resources, is that water resource, which is aimed to the supply of drinking water to households, shall only serve to this purpose in the line with the principle of sustainability and for this part it is not a commercial commodity. It means that it will be necessary for every underground water resource to establish where the proper border, especially in the sense of quantity, is in order to make proper reserves for public supply of drinking water. This should be measured and monitored in (for) the long term (in line with principle of sustainability). The border lines of quantity should be newly established in order to increase the reserves and to prevent their decreasing. ${ }^{38}$

Namely, the needs of future generations shall be taken into account. For instance, if there is no rain period of three months and it is therefore necessary to reduce the consumption due to the unavailability of the water resources, one can hardly imagine that this is a long-term approach. It means that the quantity of underground water, which now serves for commercial use whereby the same underground water resource is used also for the supply of drinking water, has to be newly established.

Recently also courts across the world have started to rule for future generations. Basically, NGO's and some individuals gave incentive and filed law suits, which enabled courts to do so. For instance, in case Janecek, ${ }^{39}$ the EU Court of Justice ruled that the individual has a right to ask for measures which the states or other competent authorities have to undertake to secure clean air. Also in the Netherland, Belgium and in Germany (possibly also in Australia), climate action has been filed for future generation (climate changes actions). ${ }^{40}$ Personally I also think that the legislators should also look further in the future and start to make difference for cases where public interest is so substantive by not allowing private interest/capital to be engaged and this way to avoid conflict of natural resources being used as a commodity. Water, more in particular - water for drinking, water for households - combine these particularities; it is of life interest, we all are end-users, it is the final product... these particularities make drinking water issues different. Awarding concessions

\footnotetext{
38 However, even current Decree on groundwater status (OJ RS, no. 25/09, 68/12 and 66/16) foresees that the available quantity of the under groundwater is a long-term average yearly degree of overall reproduction of the water resource, lowered for long term yearly flow which is needed to reach ecology quality for the surface water, which is linked to under groundwater in order to prevent lowering the quality of the underground water.

39 Case C-237/07, Dieter Janecek v Freistaat Bayern, ECLI:EU:C:2008:447.

40 'Around the World in 5 Climate Change Lawsuits' (Climate Home - climate change news, 8 July 2015) <http://www.climatechangenews.com/2015/07/08/around-the-world-in-5-climate-change-lawsuits/> accessed 19 January 2017.
} 
to drinking water supply under the same conditions as any other concession where such particularities are not present is not appropriate. Being benevolent to concessions is possible for services where no natural resources are used in the foreground of the service. ${ }^{41}$ When natural resources are in the foreground of the services, concessions should not be a first thought or a plan; this does not mean that the market approach should be at the outset excluded where the natural resource is in abundance and renewable (it is possible, by applying principle of sustainability and proportionality). Therefore, the constitutional provision divides between drinking water and non-market approach and on the other hand water resources for other, commercial purposes. To shorten, drinking water and its supply distinguish so much from other public services of commercial character that it cannot be treated the same. Drinking water, in these circumstances, is simply not commodity in all aspects. Drinking water and its supply to households therefore justify different treatment.

In the past we used to acknowledge that private companies pursued also public interest; this is not often the case nowadays. Nowadays this element is called "a responsibility to society" (slo: družbena odgovornost). This element is decreased in the circumstances where surviving on the market is difficult (i.e. in case of crises). This is, unfortunately, rather normal. Counting that private companies will serve predominantly to public interest and neglecting profit is, I would say, illusory.

\section{LITERATURE:}

1. ARSO: Količinsko stanje podzemnih voda v Sloveniji, Osnove za NUV 20152012, http://www.arso.gov.si/vode/podzemne\%20vode/)

2. Communication from the Commission on the European Citizens' Initiative "Water and sanitation are a human right! Water is a public good, not a commodity!" Brussels, 19.3.2014 COM(2014) 177 final.

3. Igor Zobavnik, Pitna voda - Primerjalni pregled, RS Državni zbor, Raziskovalno-dokumentacijski sektor, Ljubljana, 2015.

4. The Rt Hon lady Justice Arden, Water for all? Developing a human right to water in national and international law, ICLQ vol 65, October 2016, str. 771-789

5. Pravna klinika za varstvo okolja, 2014/2015, Odgovornost države zagotavjati pravico do čiste pitne vode, več avtorjev, Ljubljana, July 2015.

6. Matej Avbelj, 'Pitna voda: ustavna prepoved in ne pravica' 24.11.2016 Pravna praksa p. 3;

${ }_{41}$ See in this respect above references to articles, which discus cursing of natural resources (n 32). 
7. Aleš Ferčič and Rajko Knez, 'Organizational Challenges of the (Local) Water Supply in the European Union Member States' (2015) 13 Lex localis - Journal of Local Self-Government 765.

8. United Nations Conference on Environment and Development (UNCED) in Rio de Janeiro 1992 - Agenda 21, https://sustainabledevelopment.un.org/content/documents/Agenda21.pdf (14 January 2017).

9. Simona Drevenšek, Jan Bratinič, 'Voda je velik posel' Cvet kapitala-poslovni tednik Dela (1 June 2017) p. 12-14.

10. Rhys Andrews, Goerge A. Boyne, Richard M. Walker, 'Dimensions of Publicness and Organizational Performance: A Review of the Evidence' JPart 21 Journal of Public Administrationn Research and Theory i301.

11. Donato De Rosa and Mariana Lootty, 'Are Natural Resources Cursed? An Investigation of the Dynamic Effects of Resource Dependence on Institutional Quality' The World Bank Europe and Central Asia Region Financial Sectors Development July 2012;

12. Kolar, Tea, 'Vloga prava $\mathrm{v}$ procesu prilaščanja in prekomerne rabe naravnih dobrin' <http://www.jm-excellence.si/wp-content/uploads/2014/01/Student-paper-Nr-2-Tea-Kolar-Vloga-prava-v-procesu-prila\%C5\%A1\%C4\%8Danja-in-prekomerne-rabe-naravnih-dobrin.pdf> accessed 18 December 2016;

13. Kirn, Andrej, 'Ekosicalizem kot povezava družbenosti in sonaravnosti: Realna aternativa ali utopija' 2016 Varstvo narave 49;

14. Pihlar, Tatjana, 'V Slovenskih gozdovih se na veliko krade' (Dnevnik) <https:// www.dnevnik.si/1042536338> accessed 18 December 2016.

15. Joseph Stiglitz, Vračanje prekletstva resursov, Finance 158/2004, 16.8.2004;

16. Gorger Soros, 'Prekletstvo Naravnih Virov' (Finance.si) <https://www.finance. si/52901> accessed 19 January 2017.

17. Mariborski vodovod bi vodo prodajal v Azijo, DELO, 17.10.2015

18. Jadranka Sovdat: Ustavno Sodišče ne more biti medijska senzacija!' (Dnevnik) <https://www.dnevnik.si/1042757014> accessed 25 December 2016.

19. Golobič, Teja in Pirnat Rajko, Pravna ureditev oskrbe z vodo, Javna uprava, 2016, Nr. 1-2, p. 85-106. 